\title{
Dental disorders and self-perception of oral health in patients with
}

\section{paracoccidioidomycosis}

\author{
Alterações dentais e autopercepção da saúde bucal em pacientes com paracoccidioidomicose \\ Trastornos dentales Y salud bucal autopercibida en pacientes con paracoccidioidomicosis
}

Received: 12/28/2020 | Reviewed: 12/30/2020 | Accept: 12/31/2020 | Published: 01/04/2021

Karla Ferreira Dias Saldanha

ORCID: https://orcid.org/ 0000-0001-8706-2455 Federal University of Mato Grosso do Sul, Brazil

E-mail: karlafsaldanha@gmail.com

Bruna Karen Córdoba Penteado

ORCID: https://orcid.org/ 0000-0002-5128-2162 São Julião Hospital, Brazil

E-mail: bruna.cordoba03@gmail.com

Igor Valadares Siqueira

ORCID: https://orcid.org/ 0000-0002-5627-206X Federal University of Mato Grosso do Sul, Brazil E-mail: igorvaladares@gmail.com

Ellen Cristina Gaetti Jardim

ORCID: https://orcid.org/ 0000-0003-2471-465X Federal University of Mato Grosso do Sul, Brazil E-mail: ellen.jardim@ufms.br

Rinaldo Poncio Mendes

ORCID: https://orcid.org/ 0000-0002-0661-5917 Federal University of Mato Grosso do Sul, Brazil E-mail: tietemendes@terra.com.br

Anamaria Mello Miranda Paniago ORCID: https://orcid.org/ 0000-0002-8925-7712 Federal University of Mato Grosso do Sul, Brazil E-mail: anapaniago@yahoo.com.br

\begin{abstract}
Paracoccidioidomycosis, a systemic fungal disease, can lead to dental disorders. As studies on dental problems in patients with paracoccidioidomycosis are few, we evaluated dental disorders and self-perceived oral health in this population. The objective is to evaluate the oral condition of patients with paracoccidioidomycosis as well as their perception of the problem through a cross-sectional study of 52 adult patients with current or previous paracoccidioidomycosis in a reference hospital in Mato Grosso do Sul between December 2017 and July 2018. Demographic data, dental history, and self-perception of oral health were obtained from the National Oral Health Survey-SB Brazil 2010. The number of permanent decayed, missing, or filled teeth; presence and intensity of gingival bleeding; dental calculus; periodontal pockets; and periodontal attachment loss were recorded. Most patients had chronic paracoccidioidomycosis $(\mathrm{n}=50 ; 96.2 \%)$, with involvement of the mouth in the active phase of the disease $(\mathrm{n}=38 ; 73.1 \%)$. Participants had a high number of decayed, missing, or filled teeth (median: 30 teeth). The most compromised component was "missing" teeth (median of 21 teeth), and total edentulism was observed in 17 patients (32.7\%). Periodontal disease was seen in 15 of 35 patients (43.3\%) who had at least one tooth. Regarding satisfaction with their oral health, 27 patients (51.9\%) reported being satisfied or very satisfied. There was no association between the degree of satisfaction with the other data. Tooth loss is the major dental problem in patients with paracoccidioidomycosis, and in patients with teeth, periodontal disease was highly prevalent. A general positive selfperception of oral health observed in these patients may reduce their willingness to seek dental treatment.
\end{abstract}

Keywords: Paracoccidioidomycosis; Periodontal disease; Oral health; DMF index.

\section{Resumo}

Include the abstract in Portuguese A paracoccidioidomicose, uma doença fúngica sistêmica, pode causar distúrbios dentais. Como os estudos sobre problemas odontológicos em pacientes com paracoccidioidomicose são poucos, avaliamos os distúrbios dentais e a autopercepção da saúde bucal nesta população. O objetivo é avaliar a condição bucal de pacientes com paracoccidioidomicose bem como sua percepção do problema por meio de um estudo transversal de 52 pacientes adultos com paracoccidioidomicose atual ou prévia em hospital de referência em Mato Grosso do Sul entre dezembro de 2017 e julho de 2018. Dados demográficos, história dentária e autopercepção da saúde bucal foram obtidos no National Pesquisa de Saúde Bucal - SB Brasil 2010. O número de dentes permanentes cariados, perdidos ou obturados; presença e intensidade de sangramento gengival; cálculo dentário; bolsas 
periodontais; e perda de inserção periodontal foram registrados. A maioria dos pacientes apresentava paracoccidioidomicose crônica $(n=50 ; 96,2 \%)$, com acometimento da boca na fase ativa da doença $(n=38 ; 73,1 \%)$. Os participantes tinham um grande número de dentes cariados, perdidos ou obturados (mediana: 30 dentes). O componente mais comprometido foi dente "ausente" (mediana de 21 dentes), e edentulismo total foi observado em 17 pacientes $(32,7 \%)$. Doença periodontal foi observada em 15 de 35 pacientes $(43,3 \%)$ que tinham pelo menos um dente. Em relação à satisfação com a saúde bucal, 27 pacientes $(51,9 \%)$ referiram estar satisfeitos ou muito satisfeitos. Não houve associação entre o grau de satisfação com os demais dados. A perda dentária é o principal problema dentário em pacientes com paracoccidioidomicose e, em pacientes com dentes, a doença periodontal foi altamente prevalente. Uma autopercepção geral positiva da saúde bucal observada nesses pacientes pode reduzir sua vontade de procurar tratamento odontológico.

Palavras-chave: Paracoccidioidomicose; Doenças periodontais; Saúde bucal; Índice CPO.

\section{Resumen}

La paracoccidioidomicosis, una enfermedad fúngica sistémica, puede provocar trastornos dentales. Como los estudios sobre problemas dentales en pacientes con paracoccidioidomicosis son pocos, evaluamos los trastornos dentales y la salud bucal autopercibida en esta población. El objetivo es evaluar la condición bucal de pacientes con paracoccidioidomicosis así como su percepción del problema a través de un estudio transversal de 52 pacientes adultos con paracoccidioidomicosis actual o previa en un hospital de referencia en Mato Grosso do Sul entre diciembre de 2017 y julio de 2018. Los datos demográficos, antecedentes dentales y autopercepción de la salud bucal se obtuvieron del National Encuesta de salud bucal — SB Brasil 2010. El número de dientes permanentes con caries, perdidos o obturados; presencia e intensidad de sangrado gingival; cálculo dental; bolsas periodontales; y se registró la pérdida de inserción periodontal. La mayoría de los pacientes presentaba paracoccidioidomicosis crónica $(\mathrm{n}=50$; $96,2 \%)$, con afectación de la boca en la fase activa de la enfermedad $(n=38 ; 73,1 \%)$. Los participantes tenían una gran cantidad de dientes cariados, faltantes o obturados (mediana: 30 dientes). El componente más comprometido fueron los dientes "faltantes" (mediana de 21 dientes), y se observó edentulismo total en 17 pacientes (32,7\%). Se observó enfermedad periodontal en 15 de 35 pacientes $(43,3 \%)$ que tenían al menos un diente. En cuanto a la satisfacción con su salud bucal, 27 pacientes $(51,9 \%)$ informaron estar satisfechos o muy satisfechos. No hubo asociación entre el grado de satisfacción con los otros datos. La pérdida de dientes es el principal problema dental en pacientes con paracoccidioidomicosis, y en pacientes con dientes, la enfermedad periodontal era muy prevalente. Una autopercepción general positiva de la salud bucal observada en estos pacientes puede reducir su disposición a buscar tratamiento dental.

Palabras clave: Paracoccidioidomicosis; Enfermedades periodontales; Salud bucal; Índice CPO.

\section{Introduction}

Paracoccidioidomycosis (PCM) is a systemic disease caused by dimorphic fungi of the genus Paracoccidioides; its geographic distribution is restricted to the American continent, from Mexico to Argentina.

Infection occurs after inhaling spores that reach the lungs, where they can spread to other organs via the lymphohematogenous route. The mouth is one of the most frequently affected organs; case series studies show that 50 to $76 \%$ of PCM patients present lesions in the mouth and/or oropharynx (Bellissimo-Rodrigues et al., 2013; Machado-Filho et al., 1960; Matos et al., 2012; Paniago et al., 2003). The lesions are, in their majority, papulo-erosive, that is, shallow mucous ulcerations with thin nipple protuberances, very similar in appearance to a blackberry, called Aguiar Pupo's moriform stomatitis (Motta \& Pupo, 1936).

Any region of the mouth can be affected, such as the gingival mucosa, lips, tongue, palate, jugal mucosa, and floor of the mouth. Most studies report that periodontal areas such as the gingival or alveolar mucosa are most affected, with the frequency of occurrence varying from $39 \%$ to $66 \%$ of the cases that presented with lesions in the mouth and/or oropharynx (Brazao-Silva et al., 2011; Verli et al., 2005; de Arruda et al., 2018; Trindade et al., 2017).

Although frequent, the involvement of periodontal areas in PCM has not been widely considered in the context of periodontal disease. Few studies show the involvement of periodontal ridges and alveolar ridges by Paracoccidioides spp., with periodontal disease and early tooth loss (de Arruda et al., 2018). Only recently, in a new proposal for the classification of gingival diseases and conditions, gingival diseases of fungal origin such as candidiasis, histoplasmosis, aspergillosis and PCM were included as periodontal disease not induced by dental plaque/biofilm (Chapple et al., 2018). 
Considering the high frequency of lesions in the periodontal area in patients with PCM, it is expected that these patients will present with poor oro-dental conditions and tooth loss, with subsequent aesthetic impairment and functional loss of chewing, decreased nutrition, speech articulation impairments and, consequently, decreased self-esteem. Rehabilitation of these functions, although possible, is limited by the typical economic conditions of this patient population (Ferreira et al., 2006; Kreve \& Anzolin, 2016).

As there are many studies on the upper air digestive tract (Brazao-Silva et al., 2011; Verli et al., 2005; de Arruda et al., 2018; Trindade et al., 2017), few studies on dental problems (de Arruda et al., 2018), and none that focus on the selfperception of oral health in this population, this study aims to analyze the clinical-dental aspects, the dental condition, and the self-perception of oral health of PCM patients.

\section{Methodology}

An epidemiological, observational, cross-sectional study (Hennekens and Buring, 1987) to assess the dental aspects and self-perception of oral health in patients with PCM was conducted from December 2017 to July 2018 at the University Hospital of the Faculdade de Medicina of the Federal University of Mato Grosso do Sul, a state of the Midwestern Brazil, where PCM is endemic. The hospital where the study was carried out is a tertiary referral of the Unified Health Care System for Infectious and Parasitic Diseases throughout the state. Data were collected prospectively. During the study period, all patients meeting the eligibility criteria were invited to participate in the study.

\section{Inclusion and exclusion criteria}

Adult patients (18 years old or older) with PCM were included for the study, independent of the treatment and disease stage. Patients with infectious, inflammatory, or neoplastic comorbidities were excluded.

\section{Case definition}

A patient was considered to having PCM if suggestive clinical manifestations of the disease were present and when the typical yeast forms of Paracoccidioides spp. were identified by direct mycological examination, culture, or histopathological examination of different clinical samples and biopsied tissues.

\section{Demographic and clinical data}

Age, sex, skin color, level of education, household income, occupation, and smoking habits were recorded by interview before the dental clinical evaluation. Monthly household income was calculated based on wages accrued in the previous month and reported in units of the Brazilian minimum wage, which was R\$ 998.00 per month in 2018.

Clinical data regarding PCM, such as time since diagnosis, clinical form of the disease, disease severity, and affected organs were obtained from a prospective research database of the Service. Clinical forms of the active disease were classified according to the criteria presented by Mendes et al. (2017) as acute/subacute, chronic, or mixed. The PCM chronic form was sub-classified into mild, moderate, or severe, and the acute/subacute form into moderate or severe based on the general level of impairment, including nutritional condition/weight loss, involved organs, severity of pulmonary involvement, type of lymph node enlargement, presence of hepatomegaly and/or splenomegaly, and serum antibody titer by the double agar gel immunodiffusion test. The mixed forms were defined as severe disease. 


\section{Treatment}

Patients were treated with itraconazole or with the sulfamethoxazole-trimethoprim combination, also called cotrimoxazole $(\mathrm{CMX})$, regarding the Brazilian Consensus on Paracoccidioidomycosis. Treatment with itraconazole was maintained for at least 1 year, whereas the cotrimoxazole was continued for at least 2 years. After this period, the drug was discontinued if the patient had reached and maintained serological cure for 6 months. For patients whose initial serology was unreactive, treatment length was as described above.

\section{Dental clinical evaluation}

Oral examinations were performed using a flat mouth mirror and the periodontal probe recommended by the World Health Organization (WHO) for epidemiological surveys. The following individual indices were recorded: a) DMFT index. This is the sum of the number of permanent decayed, missing, or filled teeth in each participant. All teeth in each participant were examined; b) Periodontal Condition Index (PCI). This is based on the presence and intensity of gingival bleeding, dental calculus, and presence of periodontal pockets in each participant; c) Periodontal Attachment Loss (PAL). This was assessed by the visibility of the cemento-enamel junction (CEJ).

The PCI and PAL scores for each patient were calculated based on the tooth in the worst condition. The intensity classification of DMFT, PCI, and PAL is shown in Table 1 . Patients with PCI > 2 and PAL > 0 were considered to have periodontal disease.

Table 1. Oral parameters used to measure DMFT, periodontal condition index, and periodontal attachment loss.

\begin{tabular}{|c|c|c|c|c|c|c|c|c|c|}
\hline \multicolumn{2}{|c|}{ DMFT } & \multicolumn{6}{|c|}{ Periodontal condition index (PCI) } & \multirow{2}{*}{\multicolumn{2}{|c|}{$\begin{array}{l}\text { Periodontal attachment loss } \\
\text { (PAL) }\end{array}$}} \\
\hline & & \multicolumn{2}{|c|}{ gingival bleeding } & \multicolumn{2}{|c|}{$\begin{array}{c}\text { dental } \\
\text { calculus }\end{array}$} & \multicolumn{2}{|c|}{$\begin{array}{c}\text { periodontal pocket depth } \\
\text { (PPD) }\end{array}$} & & \\
\hline Very low & 1.1 & 0 & No & 0 & No & 0 & No & 0 & $\leq 3 \mathrm{~mm}$ \\
\hline Low & 2.6 & 1 & Yes & 1 & Yes & 1 & Yes, $\leq 5 \mathrm{~mm}$ & 1 & $3-6 \mathrm{~mm}$ \\
\hline Moderate & 4.4 & & & & & 2 & Yes, $>5 \mathrm{~mm}$ & 2 & $6-8 \mathrm{~mm}$ \\
\hline High & 6.5 & & & & & & & 3 & $8-11 \mathrm{~mm}$ \\
\hline Very high & $\geq 6.6$ & & & & & & & 4 & $\geq 12 \mathrm{~mm}$ \\
\hline
\end{tabular}

Source: Adapted from Brazil (2012).

\section{Need for dental prosthesis or prosthesis replacement.}

The examiner considered it necessary to use or to replace some type of dental prosthesis for individuals with at least one of the following criteria: edentulous without complete dentures; lack of one or more dental elements with functional problems; presence of a prosthesis with functional problems (existing base fractures, other fractures, lack of adaptation, presence of associated oral tissues lesions, poor retention). Aesthetic concerns were not considered as an indication for the use or replacement of a dental prosthesis. 


\section{Self-perception of oral health}

Perceived oral health status was determined by the following question, from the SB Brazil project form14: "With regards to your teeth and mouth, are you...?" with five options to choose from: Very satisfied, satisfied, neither satisfied nor dissatisfied, dissatisfied, very dissatisfied. For our analysis, the responses were grouped into three categories: 1) satisfied (very satisfied + satisfied) 2) neither satisfied nor dissatisfied, and 3) dissatisfied (dissatisfied + very dissatisfied).

Five other questions about oral lesions and tooth loss over the disease course with PCM were added: Have you ever visited a dentist? Have you had PCM lesions in your mouth? Have you ever lost a permanent tooth? If yes, for what reason? Did you lose a tooth while having PCM? If yes, for what reason? If yes, who extracted your teeth?

\section{Statistical analysis}

Analysis of the association of the degree of satisfaction with oral health and the DMFT and PCI indices was performed using the Kruskal-Wallis non-parametric test. Assessment of the correlation between DMFT and PCI was performed using Spearman's linear correlation test. Statistical analyses were performed using the SPSS statistical program (version 24.0), with significance level set at $\mathrm{p} \leq 0.05$.

\section{Ethical aspects}

The project was approved by the Human Research Ethics Committee from the Federal University of Mato Grosso do Sul. Informed consent was obtained from all study participants.

\section{Results}

The 52 patients studied were mostly men $(\mathrm{n}=51 ; 98.1 \%)$, with a median age of $57(26-92)$ years, were current or previous rural workers, and with a low education level and low socioeconomic status (Table 2). Forty-six patients (88.5\%) were smokers or ex-smokers. Regarding the clinical PCM findings, the chronic form, with moderate severity, with involvement of the lungs and mouth predominated.

Table 2. Demographic and clinical characteristics of 52 paracoccidioidomycosis patients.

\begin{tabular}{lr}
\hline Variable & Median [minimum - maximum] or Number (\%) \\
\hline Age (years) & $57[26$ - 92] \\
Gender (Male) & $51(98.1)$ \\
Race/skin color & \\
White & $21(40.3)$ \\
Black & $3(5.8)$ \\
Brown & $24(46.2)$ \\
Unknown & $4(7.7)$ \\
Instruction (in years of studying) & $4[0 \mathrm{a} 10]$ \\
Monthly household income (in BMW) & \\
Up to 3 & $43(82.7))$ \\
3 or more & $8(15.4)$ \\
Unknown & $01(1.9)$ \\
Smoking (current or previous) & \\
Yes (current) & $43(82.7)$
\end{tabular}


Yes (previous)

No/never

Unknown

Rural worker (current or previous)

Yes (current)

Yes (previous)

$29(54.7)$

No/never

Unknown

Time between PCM diagnosis and dental evaluation (years)

Stage of PCM treatment

In course

Finished

\section{PCM clinical form}

Acute/subacute

Mixed

Chronic

\section{Severity}

Mild

Moderate

Severe

Organs involved*

Lungs

Mouth

Larynx

Skin

Lymph nodes

Adrenal glands

BMW = Brazilian minimum wage; * A patient could present with more than one affected organ. Source: Authors.

The dental clinical examination showed that almost one third of the patients $(\mathrm{n}=17 ; 32.7 \%)$ were edentulous, and the majority $(n=45 ; 86.5 \%)$ needed a dental prosthesis or replacement of the prosthesis used (Table 3$)$. $(n=45 ; 86.5 \%)$. Among the 52 patients, a median DMFT of 30 was observed, while among the 35 participants who had at least 1 tooth, 15 (42.9\%) had periodontal disease (Table 3). 
Table 3. Oral, dental, and periodontal conditions of the 52 patients with paracoccidioidomycosis.

or Median [minimum - maximum]

\section{Edentulous}

No

Yes

\section{Dental prosthesis}

No

Yes

Need prosthesis replacement

Edentulous

Non-edentulous

Total

Need prosthesis

Edentulous

Non-edentulous

Total

DMFT

Decayed

Missing

Filled

DMFT index

Periodontal condition $\left(n=35^{*}\right)$

Gingival bleeding

Dental calculus

Periodontal bag

Periodontal attachment loss $(\mathrm{PAL})>0$

Periodontal condition index $(\mathrm{PCI})>2 * *$

Periodontal disease $(\mathrm{PCI}>2$ and $\mathrm{PAL}>0)$

PCM sequelae in mouth $(n=38 * *)$ 
DMFT: Decayed-Missing-Filled Teeth; * Evaluated only in the 35 non-edentulous patients; **Only patients who had buccal lesions by PCM. Source: Authors.

Self-reported oral health and dental care. Almost half of the 35 dentate individuals $(n=14 ; 40 \%)$ reported having toothache in the last year, and half of them $(n=7)$ consulted a dentist only two years ago or more.

Self-perceived oral condition. More than half of the patients reported being very satisfied or satisfied with their teeth/mouth $(\mathrm{n}=27 ; 51.93 \%)$. Although the majority reported being satisfied, more than one third of the patients $(\mathrm{n}=19$; $36.54 \%$ ) reported having difficulties speaking or feeling ashamed because of their teeth.

A lost tooth due non-traumatic mobility was reported by $72 \%$ of the 50 patients that have lost at least one permanent tooth (Table 4).

Table 4. Dental history of the 52 patients with paracoccidioidomycosis.

\begin{tabular}{lr}
\hline Variable & Number (\%) \\
\hline Have you ever visited a dentist? & $-(-)$ \\
No & $52(100.0)$ \\
Yes & $14(26.9)$ \\
Have you had PCM lesions in your mouth? & $38(73.1)$ \\
No & \\
Yes &
\end{tabular}

Have you ever lost a permanent tooth?

No

Yes

If yes, for what reason? $(n=50)$

Non-traumatic mobility

Other condition

Did you lose a tooth while having PCM? $(n=50)$

No

Yes

If yes, for what reason? $(n=28)$ 
Non-traumatic mobility

Other condition

If yes, who extracted your teeth? $(n=28)$

A dentist

Myself

$09(18.0)$

Both

Source: Authors

There was no association between the self-perception of oral health, measured by the degree of satisfaction, with the index of missing, filled and decayed teeth (DMFT) or the periodontal condition index (PCI) (Table 5).

Table 5. Association between the index of missing, filled and decayed teeth (DMFT) or the periodontal condition index (PCI) with the degree of satisfaction of the health of the teeth/mouth of the 52 paracoccidioidomycosis patients.

\begin{tabular}{|c|c|c|c|c|}
\hline \multirow{3}{*}{ Variable } & \multicolumn{3}{|c|}{ Self-perception of oral health } & \multirow{3}{*}{ P value * } \\
\hline & \multicolumn{3}{|c|}{ Median [minimum- maximum] } & \\
\hline & Satisfied & $\begin{array}{l}\text { Neither satisfied nor } \\
\text { dissatisfied }\end{array}$ & Dissatisfied & \\
\hline DMFT & $28[6-32]$ & $28[0-32]$ & $24[12-32]$ & 0.882 \\
\hline PCI & $1[0-5]$ & $3[0-6]$ & $2[0-5]$ & 0.224 \\
\hline
\end{tabular}

*Kruskal-Wallis test. Source: Authors.

The need to use or replace a dental prosthesis was lower according to the patient's self-perception than according to the examiner's assessment (Table 6). This self-perception was higher in edentulous patients than in those with teeth (76.5\% vs $28.8 \% ; \mathrm{p}=0.036)$. 
Table 6. Comparison between patient self-perception and indication by the examiner for the need for a prosthesis or prosthesis replacement.

\begin{tabular}{|c|c|c|c|}
\hline \multirow[t]{2}{*}{ Need prosthesis or prosthesis replacement } & \multicolumn{2}{|c|}{ Examiner's indication } & \multirow[t]{3}{*}{ P value* } \\
\hline & \multicolumn{2}{|c|}{$\mathbf{N}(\%)$} & \\
\hline Patient self-perception & No $(n=7)$ & Yes $(n=45)$ & \\
\hline No & 7 & 14 & 0.002 \\
\hline Yes & - & 27 & \\
\hline Don't know/didn't answer & - & 4 & \\
\hline
\end{tabular}

Do not know/did not answer were excluded from the analysis; *Fisher's exact test. Source: Authors.

There was a moderate indirect linear correlation between the DMFT and PCI+PAL of the patients $(r=-0.714 ; \mathrm{p}<$ 0.001), showing the presence of periodontal disease (Figure 1).

Figure 1. Scatter plot illustrating the moderate negative linear correlation between DMFT and PCI+PAL. Spearman's linear correlation test.

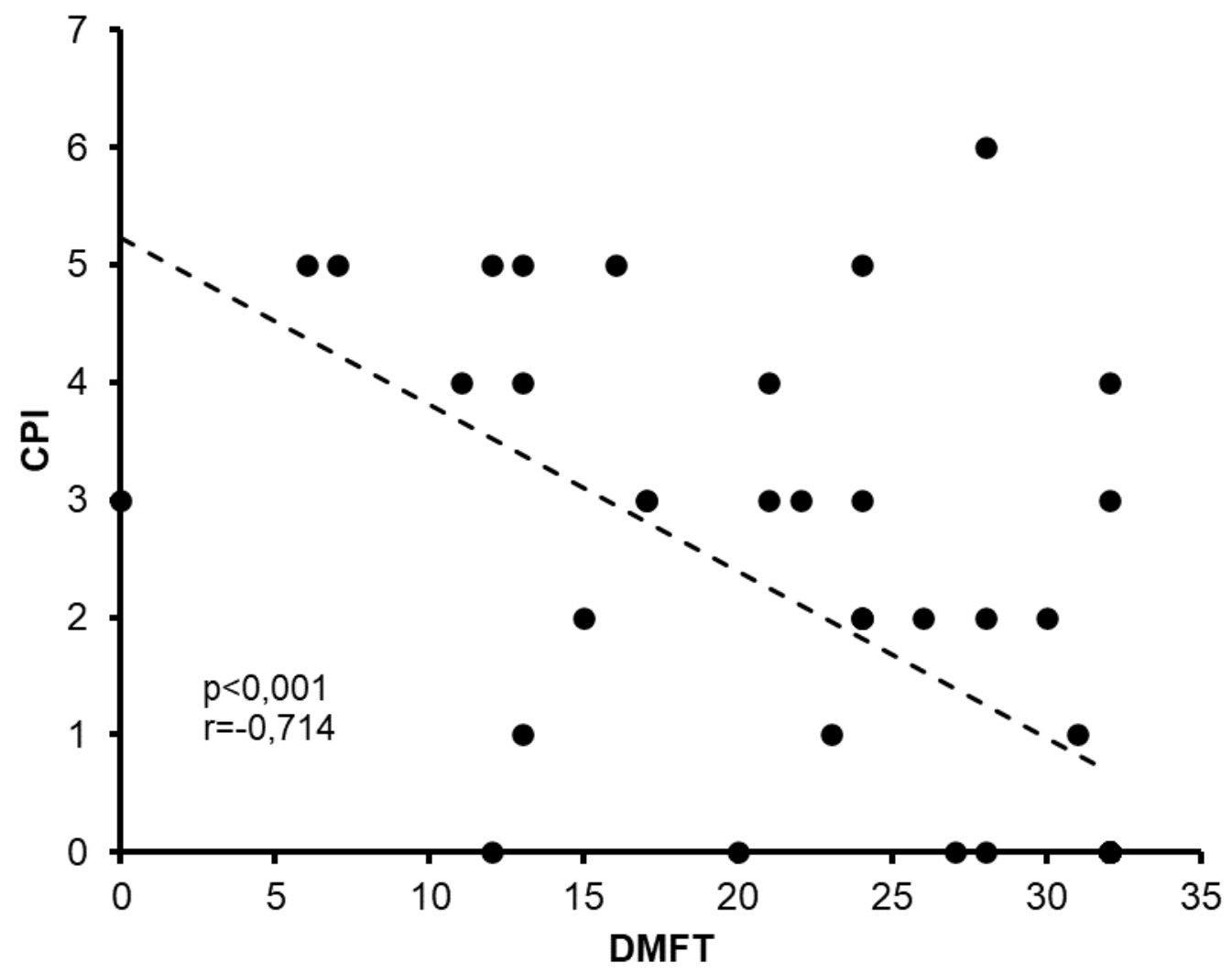

Source: Authors. 


\section{Discussion}

The patients in this study were mostly male rural workers, with little education and low income, similar to that observed in most PCM studies (Bicalho et al., 2001; Bellissimo-Rodrigues et al., 2011; Martinez, 2015), demonstrating that this sample is largely representative of the typical patient population. This patient population has difficulty accessing dental services, and besides, they have a low level of demand for their oral. In addition, half of the patients had a family income below 1.5 Brazilian minimum wages, which is associated with a higher rate of tooth loss (Kreve \& Anzolin, 2016).

Although the involvement of the upper aerodigestive tract is frequent in PCM patients with the chronic form and rare in those with the acute/subacute form, periodontal lesions were reported in this last clinical form (Migliari et al., 1998).

This study showed that tooth loss is the major dental problem in patients with PCM, and disparity exists between the severity of the individual's oral condition and self-perception of oral health. Periodontal disease was observed in patients with PCM both during and after treatment of the infection.

This study showed a high prevalence of the "missing" component of the DMFT index between the 4th and 5th decade of life, indicating early tooth loss. This result was significantly higher than that observed in adults in the general population of São Paulo and is similar to that in elderly individuals in São Paulo and Brazil (Brasil, 2012; Gibilini et al., 2010).

The need to use or replace dental prostheses was frequent in the patients in our study, probably because tooth extraction is considered a practical and economical means to resolve the periodontal disease. However, most patients undergoing tooth extraction cannot afford dental implants or prostheses (Braga et al., 2002).

In general, in adults and the elderly, tooth loss occurs more frequently due to caries (Brasil, 2012; Murray Thomson et al, 2014). In contrast, in this study, tooth mobility resulting from periodontal disease was the main cause of tooth loss. The moderate indirect linear correlation between PCI and DMFT shows that periodontal disease still occurs in the studied group, with risk of new tooth loss.

More than half the patients in this study mentioned having teeth extracted while experiencing symptoms of active PCM due to tooth mobility. This suggests that frequent involvement of the gingiva and alveolar mucosa in the active phase of PCM led to mobility and loss of teeth (Holmstrup et al., 2018; Bisinelli et al., 2001). Thus, it is very likely that Paracoccidioides spp. was co-responsible for periodontal disease in these patients; however, the methodology used here did not allow this association to be effectively demonstrated.

Almost all the 52 patients were smokers, and smoking is a significant risk factor for illness due to PCM (Santos et al., 2003). Smoking contributes to the worsening of periodontal disease, and the negative effect of smoking on periodontal health is cumulative and dose-dependent (Kinane \& Chestnutt, 2000), which can be a confounding factor for tooth loss associated with PCM.

The sequelae of PCM are so frequent that the current classification of PCM includes them as a clinical form of the disease, the residual form (Shikanai-Yasuda et al., 2017). Periodontal disease and tooth loss have not been studied often as sequelae to PCM (do Valle et al., 1995; Machado Filho et al., 1965); however, they can irreversibly affect a patient's functional capacity for chewing and speech and diminish aesthetic appearance. Thus, we recommend that periodontal disease and tooth loss should be among the defined manifestations of the residual form of PCM. Studies defining the best dental therapeutic approaches for this patient population are lacking.

This study showed that almost one third of the individuals reported tooth extraction performed at home without the help of a professional. Periodontal disease must be detected and treated as soon as possible in this population by a dentist to prevent complications.

Yet it has been recommended to avoid dental procedures in patients with active PCM lesions in the mouth because of 
the risk of local dissemination of the fungus. During the diagnostic investigation, a patient was referred to a dental service for removal of his carious and infected teeth. On postoperative follow-up examination, a granulomatous mass appeared from the canine socket and, later, a second mass was detected on the hard palate. The histopathological examination of a biopsied tissue from the second lesion confirmed the paracoccidioidal etiology (Salman \& Sheppard, 1962). As a result, evaluation by a dentist in this population is usually postponed until the disappearance of active PCM lesions. In our opinion, this delay in dental evaluation of PCM patients should be avoided whenever possible, considering that many patients extract their own teeth at home, without appropriate follow-up care. Another aspect to be considered is that delaying treatment for periodontal disease is a risk factor for disease progression, leading to tooth loss and other serious complications, such as cardiovascular disease (Mattila et al., 2005). If the need for dental evaluation and treatment is reinforced in each medical consultation with PCM patients, a large percentage of dental loss in this population could be avoided.

Regarding self-perception of oral health, most patients in this study were satisfied and had few complaints related to their teeth, in contrast to the physical examination that revealed periodontal disease in most of them, as well as a high DMFT index. The studied patients had few resources, not only financial, but also educational and health-related, which probably contributed to the satisfaction with their oral health. In addition to these limiting socioeconomic factors, because general health is usually prioritized when seeking treatment, dental problems represent a secondary problem, which does not require immediate evaluation and treatment (Jokovic \& Locker, 1997).

Some negative impacts on quality of life, such as psychological discomfort and pain, were noted in this study. However, in general, oral problems interfered little in the ability to perform daily activities or in relationships. Likewise, there was a low perception of the need for a dental prosthesis or prosthesis replacement, with more edentulous individuals being more perceptive to this need than patients with residual teeth. Therefore, it is important to improve competency in assessing oral health among primary care physicians, since preventive care and health education are associated with both self-perception of the need for dental prostheses and self-perception of the need for dental treatment (Dalazen et al., 2018). The poor oral condition observed in the patients in this study also reflects the lack of general oral health care in this population.

This study has some limitations. The cross-sectional design of the study and the relatively small number of participants did not allow assessment of factors associated with the risk of tooth loss in these patients. The group was highly homogeneous in terms of age, sex, socioeconomic aspects, and smoking history, which hindered a comparative analysis regarding self-perception of oral health.

\section{Conclusion}

The findings presented here reveal clinically significant dental problems in PCM patients; however, any intervention to recover the oral health in this population will depend on the individual patient's motivation for compliance to dental treatment. This motivation is compromised considering the lack of awareness regarding poor oral health among these patients. Therefore, health care providers must work continuously to increase the awareness of oral health issues in PCM patients.

Further longitudinal studies are suggested in patients with active PCM and oral lesions, in order to monitor the periodontal involvement by both an otolaryngologist and a dentist, in order to reduce the risk of early tooth loss associated with the disease.

\section{Acknowledgments}

We thank Associação de Auxílio e Recuperação dos Hansenianos - Hospital São Julião, Campo Grande, MS, Brasil where the odontological examination were performed, Fundação de apoio ao Desenvolvimento do Ensino, Ciência e 
Tecnologia do estado de Mato Grosso do Sul (FUNDECT) and Coordenação de Aperfeiçoamento de Pessoal de Nível Superior (CAPES) for supporting this work.

\section{References}

Bellissimo-Rodrigues, F., Bollela, V. R., Da Fonseca, B. A., Martinez, R. (2013). Endemic paracoccidioidomycosis: relationship between clinical presentation and patients' demographic features. Med Mycol, 51:313-8.

Bellissimo-Rodrigues, F., Machado, A. A., Martinez, R. (2011). Paracoccidioidomycosis epidemiological features of a 1,000-cases series from a hyperendemic area on the southeast of Brazil. Am J Trop Med Hyg, 85:546-50.

Bicalho, R. N., Santo, M. F., de Aguiar, M. C., Santos, V. R. (2001). Oral paracoccidioidomycosis: a retrospective study of 62 Brazilian patients. Oral Dis, 7:56-60.

Bisinelli, J. C., Telles, F. Q., Sobrinho, J. A., Rapoport, A. (2001). Stomatological manifestations of paracoccidioidomycosis. Rev Bras Otorrinolaringol, 67:683-7.

Braga, S., Telarori- Jr, R., Braga, A., Catirse, A. (2002). Avaliação das condições e satisfação com as próteses em idosos na região Central do Estado de São Paulo (Brasil). Rev Odontol UNESP, 31:39-48.

Brasil. (2012). SB Brasil 2010: Pesquisa Nacional de Saúde Bucal: resultados principais. Secretaria de Atenção à Saúde, Saúde SdVe, editors. Brasília: Ministério da Saúde, p. 116.

Brazao-Silva, M. T., Andrade, M. F., Franco, T., Ribeiro, R., Silva, W. D., Faria, G. et al. (2011). Paracoccidioidomycosis: a series of 66 patients with oral lesions from an endemic area. Mycoses, 54:E189-95.

Chapple, I. L.C., Mealey, B. L., Van Dyke, T. E., Bartold, P. M., Dommisch, H., Eickholz, P., et al. (2018).Periodontal health and gingival diseases and conditions on an intact and a reduced periodontium: Consensus report of workgroup 1 of the 2017 World Workshop on the Classification of Periodontal and Peri-Implant Diseases and Conditions. J Periodontol, 89 Suppl 1:S74-84.

de Arruda, J. A. A., Schuch, L. F., Abreu, L. G., Silva, L. V. O., Mosconi, C., Monteiro, J. L. G. C., et al. (2018). A multicentre study of oral paracoccidioidomycosis: Analysis of 320 cases and literature review. Oral Dis, 24:1492-502.

Dalazen, C., Bomfim, R., De-Carli, A. (2018). Fatores associados à autopercepção da necessidade de tratamento odontológico e de prótese em idosos brasileiros. Cien Saude Colet, 23:945-52.

do Valle, A. C., Aprigliano Filho, F., Moreira, J. S., Wanke, B. (1995). Clinical and endoscopic findings in the mucosae of the upper respiratory and digestive tracts in post-treatment follow-up of paracoccidioidomycosis patients. Rev Inst Med Trop Sao Paulo, 37:407-13.

Ferreira, A. A. A., Piuvezam, G., Werner, C. W. A., Alves, M. S. C. (2006). A dor e a perda dentária: representações sociais do cuidado à saúde bucal. Cien Saude Colet, 11:211-8.

Gibilini, C., Esmeriz, C., Volpato, L., Meneghim, Z., Silva, D., Sousa, M. (2010). Acesso a serviços odontológicos e auto-percepção da saúde bucal em adolescentes, adultos e idosos. Arq Odontol, 46:213-23.

Hennekens, C. H. \& Buring, J. E.. Epidemiology in Medicine. Library of Congress, Boston: Little Brown. 1997.

Holmstrup, P., Plemons, J., Meyle, J. (2018). Non-plaque-induced gingival diseases. J Periodontol, 89 Supp1 1:S28-S45.

Jokovic, A., \& Locker, D. (1997). Dissatisfaction with oral health status in an older adult population. J Public Health Dent, 57:40-7.

Kinane, D. F. \& Chestnutt, I. G. (2000). Smoking and periodontal disease. Crit Rev Oral Biol Med, 11:356-65.

Kreve, S., Anzolin, D. Impacto da saúde bucal na qualidade de vida do idoso. Rev Kairós Geronto, 19:45-59.

Machado-Filho, J. \& Miranda, J. L. (1960). Considerações relativas à blastomicose sul-americana. Localizações, sintomas iniciais, vias de penetração e disseminação em 313 casos consecutivos. Hospital, 58:99-137.

Machado Filho, J., Miranda, J. L., Teixeira, G. A. (1965). Das sequelas da blastomicose sul-americana. Hospital (Rio de Janeiro), 68:1347-53.

Martinez, R. (2015). Epidemiology of paracoccidioidomycosis. Rev Inst Med Trop S. Paulo, 57 Suppl 19:11-20.

Matos, W. B., Dos Santos, G. M., Silva, V. E., Rosário Gonçalves, E. G., Silva, A. R. (2012). Paracoccidioidomycosis in the state of Maranhão, Brazil: geographical and clinical aspects. Rev Soc Bras Med Trop, 45:385-9.

Mattila, K. J., Pussinen, P. J., Paju, S. (2005). Dental infections and cardiovascular diseases: a review. J Periodontol, 76 Suppl 11:2085-8.

Mendes, R. P., Cavalcante, R. S., Marques, S. A., Marques, M. E. A., Venturini, J., Sylvestre, T. F. et al. (2017). Paracoccidioidomycosis: Current perspectives from Brazil. Open Microbiol J, 11:224-82.

Migliari, D. A., Sugaya, N. N., Mimura, M. A., Cucé, L. C. (1998). Periodontal aspects of the juvenile form of paracoccidioidomycosis. Rev Inst Med Trop Sao Paulo, 40:15-8. 
Research, Society and Development, v. 10, n. 1, e11010111557, 2021 (CC BY 4.0) | ISSN 2525-3409 | DOI: http://dx.doi.org/10.33448/rsd-v10i1.11557

Motta, L. \& Pupo, J. (1936). Granulomatose paracoccidioidica (blastomycose brasileira). An Fac Med São Paulo, 12:407-26.

Murray Thomson, W. (2014). Epidemiology of oral health conditions in older people. Gerodontology, 31 Suppl 1:9-16.

Paniago, A. M., Aguiar, J. I., Aguiar, E. S., da Cunha, R. V., Pereira, G. R., Londero, A. T. et al. (2003). Paracoccidioidomycosis: a clinical and epidemiological study of 422 cases observed in Mato Grosso do Sul. Rev Soc Bras Med Trop, 36:455-9.

Salman, L., Sheppard, S. M. (1962). South American blastomycosis. Oral Surg Oral Med Oral Pathol, 15:671-6.

Santos, W. A., Silva, B. M., Passos, E. D., Zandonade, E., Falqueto, A. (2003). Association between smoking and paracoccidioidomycosis: a case-control study in the State of Espírito Santo, Brazil. Cad Saude Publica, 19:245-53.

Shikanai-Yasuda, M. A., Mendes, R. P., Colombo, A. L., Queiroz-Telles, F., Kono, A. S. G., Paniago, A. M. M. et al. (2017). Brazilian guidelines for the clinical management of paracoccidioidomycosis. Rev Soc Bras Med Trop, 50:715-40.

Trindade, A. H., Meira, H. C., Pereira, I. F., de Lacerda, J. C. T., de Mesquita, R. A., Santos, V. R. (2017). Oral paracoccidioidomycosis: Retrospective analysis of 55 Brazilian patients. Mycoses, 60:521-5.

Verli, F. D., Marinho, S. A., Souza, S. C., Figueiredo, M. A., Yurgel, L. S. (2005). Clinical-epidemiologic profile of paracoccidioidomycosis at the Stomatology Department of São Lucas Hospital, Pontificia Universidade Católica of Rio Grande do Sul]. Rev Soc Bras Med Trop, $38: 234-7$. 